\title{
Efficiency of application of Trichoderma on the physiological quality and health of cowpea seeds
}

\author{
Higor Barbosa Reis' ${ }^{1}$, Artenisa Cerqueira Rodrigues², Aloisio Freitas Chagas Junior' , \\ Aurenivia Bonifácio², Gil Rodrigues dos Santos ${ }^{1}$
}

\author{
'Federal University of Tocantins, Gurupi, Brazil. \\ ${ }^{2}$ Federal University of Piauí, Teresina, Brazil. \\ *Corresponding author, email: gilrsan@uft.edu.br
}

\begin{abstract}
One of the main causes of low productivity of cowpea crops in Brazil is the use of low quality seeds. Low quality seeds have a high degree of infestation by phytopathogens, mainly fungi. Seed treatment with biological control agents, such as fungi of the genus Trichoderma, is a useful alternative to reduce or inhibit the transmission of diseases via seeds. In view of the above, this study aims to evaluate the physiological and sanitary quality of cowpea seeds treated with conidia of Trichoderma sp. $\left(1.2,2.4,4.8\right.$ and $\left.9.6 \times 10^{8} \mathrm{CFU} \mathrm{g}^{-1}\right)$. We evaluated the germination and the sanity of seeds, length of seedling radicles, and production of indole acetic acid (IAA) by fungi. The experimental design was completely randomized in all experiments. In general, there was a predominance of Fusarium spp. and Rhizoctonia solani. The treatment of seeds with the conidia of Trichoderma sp. was positive for the parameters related to germination and radicle length of cowpea beans up to the concentration $4.8 \times 10^{8} \mathrm{CFU} \mathrm{g}^{-1}$. We conclude that the application of Trichoderma sp. was efficient in reducing the incidence of Fusarium spp., and promoted the germination and elongation of the radicle in cowpea.
\end{abstract}

Keywords: Vigna unguiculata, germination, fungus, indole acetic acid.

\section{Introduction}

In the state of Tocantins, cowpea has been cultivated mainly in tropical lowland areas. The planted area is approximately 3.5 thousand hectares, the annual production is 4.5 thousand tons, and there is a low productivity (SEAGRO, 2012). One of the main causes of such a low productivity of cowpea crops in Brazil is the use of low quality seeds (Rey et al., 2009). The increase in investments in technologies aiming to increase the productivity of cowpea in the region has led to an increase in the acceptance of cowpea by traders, agroindustries, distributors and consumers (Freire Filho et al., 2009; Dutra et al., 2012).

The best quality cowpea seeds are the consequence of a positive interaction of genetic, environmental, physiological and, especially, health factors (Teixeira et al., 2012; Dutra et al., 2012). Low quality seeds have a high degree of infestation by phytopathogens, mainly fungi. They reduce germination and can disseminate, establishing primary foci of infection (Barbosa et al., 2011; Kobayasti \& Pires, 2011; Dutra et al., 2012). In this context, seed health analysis is an important tool for providing information on the incidence of phytopathogens, and serves as the basis for the choice of control methods (Rey et al., 2009; Dutra et al. 2012).

Seed treatment with biological control agents, such as fungi of the genus Trichoderma, 
is a useful alternative to reduce or inhibit the transmission of diseases via seeds (Corrêa et al., 2008; Harman, 2011; Oliveira et al., 2012). The fungi of the genus Trichoderma easily propagate. They are able to survive in unfavorable environments and act efficiently as biological control agents (Brotman et al., 2010; Mastouri et al., 2010; Machado et al., 2011). In addition, they are antagonists of several phytopathogen species, in addition to promoting improvements in plant growth and defense against pathogen populations in different soil types without causing a negative impact on the environment (Vinale et al., 2008; Silva et al., 2011 ; Zhang et al., 2012).

In view of the above, this study aims to evaluate the physiological and sanitary quality of cowpea seeds inoculated with different concentrations of conidia of Trichoderma sp.

\section{Material and Methods}

We used cowpea seeds (Vigna unguiculata (L.) Walp.) of the 'Vinagre' cultivar. Prior to the beginning of the tests, the seeds were treated with conidia of Trichoderma sp. at concentrations of 1.2, 2.4, 4.8 and $9.6 \times 10^{8} \mathrm{CFU}$ $\mathrm{g}^{-1}$. Adjustment of concentrations of Trichoderma sp. conidia was performed using a Neubaver chamber. The conidia of Trichoderma sp. were obtained from a mixture of isolates of different species of Trichoderma and T. harzianum. The control consisted of cowpea seeds not inoculated with conidia of Trichoderma sp.

For the germination and sanity test, the seeds were evenly distributed in Petri dishes containing sterile filter paper sheets moistened with sterile water. The plates were then randomly placed in an incubation chamber at $20.0 \pm 2.0$ ${ }^{\circ} \mathrm{C}$ and a 12-h photoperiod for seven days. The germination test was performed by counting the number of seeds that emitted a radicle after a period of $24 \mathrm{~h}$, and the percentage of seeds germinated per treatment was calculated. For the evaluation of sanity, the fungi present in seeds were identified with a magnifying glass and an optical microscope. Then, the percentage of infected seeds with each fungal genus identified was determined. In addition, seedlings considered normal were evaluated as for radicle length using a digital pachymeter.
To determine the rate of germination and the rate of seed-seedling fungi transmission in each treatment, the cowpea seeds were seeded in plastic trays containing washed and sterilized sand $\left(121^{\circ} \mathrm{C}, 101 \mathrm{kPa} ; 1 \mathrm{~h}\right)$. The trays were kept in greenhouse conditions throughout the evaluation period. The germination speed index (GSI) was calculated according to Maguire (1962). The first count rate was determined based on the number of seedlings germinated in each treatment after two days of sowing, and the data were expressed as percentage.

The evaluation of transmission was performed through daily observations of symptomatic emerged seedlings. Seedlings with lesions were collected, and samples of infected plant tissue were transferred to Petri dishes containing PDA (potato-dextrose-agar) culture medium. The plates were incubated for seven days at $20.0 \pm 2.0^{\circ} \mathrm{C}$ with a 12-h photoperiod for observation of fungal structures as described by Sá et al. (2011). The identification of fungi was carried out using a stereoscopic and optical microscope and specialized literature. The fungi identified in the samples were inoculated into healthy cowpea seedlings for evaluation of Koch's postulates.

The production of indole acetic acid (IAA) was evaluated in the fungal isolates found in the sanity test. For this, the isolates were transferred to Petri dishes containing TSA (Tryptone Soy Agar) culture medium, covered with a nitrocellulose membrane, and incubated at $28.0{ }^{\circ} \mathrm{C}$ for 24 hours. After, the nitrocellulose membrane was withdrawn, transferred to another plate, and then moistened with Salkowski' solution ( $2 \%$ solution of $0.5 \mathrm{M}$ ferric chloride in $35 \%$ perchloric acid; $\mathrm{v} / \mathrm{v})$. The presence of red halos in the nitrocellulose membrane, in an interval of 30 min to two hours, indicates the production of IAA by the isolates tested.

For the germination and sanity test, the experimental design was completely randomized with 10 replications, each replication consisting of a Petri dish containing 20 seeds. A completely randomized experimental design with four replicates was used to determine the germination speed index and the rate of seed-seedling fungi transmission. Each replicate comprised a plastic 
tray containing 25 seeds. The percentage data were previously transformed into sine-arc $\sqrt{ } \mathrm{x}+$ 100 , and then submitted to statistical analysis. Regression analysis was used to evaluate the effects of different concentrations of conidia of Trichoderma sp. on the seeds. Data were submitted to analysis of variance (ANOVA) and Tukey test at $5 \%$ of probability using the statistical software ASSISTAT.

\section{Results and Discussion}

The sanitary analysis of cowpea beans treated with different concentrations of conidia of Trichoderma sp. did not show efficient results in relation to the control of fungi in the seeds (Table 1). The Trichoderma are able to inhibit phytopathogen growth mainly due to their fast growth and, consequently, a high ability to compete for space and nutrients and to produce inhibitory compounds (Siameto et al., 2010). In view of this, it is probable that, in this study, there was an inability of the fungus Trichoderma sp. to compete with fungi recorded in the seeds and/or produce antifungal substances. The incidence of pathogenic fungi was recorded in all treatments, however the incidence of Fusarium spp. in the seeds treated with Trichoderma decreased when compared to the control (Table 1).

The genus Fusarium encompasses a range of widely distributed microorganisms that causes fusariosis in cowpea plants and can cause approximately $90 \%$ reductions in seed production in susceptible cultivars (Rodrigues et al., 2006; Silva et al., 2011; Teixeira et al., 2012). The use of resistant cultivars is recommended for the control of fusariosis in cowpea, but the difficulties in obtaining such cultivars encourage the search for viable alternatives to control the disease (Rodrigues et al., 2006; Teixeira et al., 2012). The use of antagonistic fungi for biological control, such as Trichoderma sp., may be a viable alternative for reducing the incidence of fungi of the genus Fusarium on cowpea.

Table 1. Sanitary analysis of cowpea seeds CV. 'Vinegar' treated with different concentrations of conidia of Trichoderma sp.

\begin{tabular}{|c|c|c|c|c|c|}
\hline \multirow{3}{*}{ Mycoflora } & \multirow{3}{*}{ Control $^{\Omega}$} & \multicolumn{4}{|c|}{ Concentrations of conidia of Trichoderma sp. } \\
\hline & & 1.2 & 2.4 & 4.8 & 9.6 \\
\hline & & \multicolumn{4}{|c|}{$\left(\times 10^{8} \mathrm{CFU} \mathrm{g}^{-1}\right)$} \\
\hline Fusarium spp. & $79.1 \%$ a & $59.4 \% \mathrm{~b}$ & $56.8 \% \mathrm{~b}$ & $60.4 \% \mathrm{~b}$ & $51.0 \% \mathrm{C}$ \\
\hline Rhizoctonia solani & $19.4 \% \mathrm{C}$ & $24.9 \%$ b & $25.8 \% \mathrm{~b}$ & $17.9 \%$ c & $32.4 \%$ a \\
\hline Aspergillus spp. & $0.5 \% \mathrm{c}$ & $14.9 \% \mathrm{~b}$ & $16.7 \%$ a & $16.8 \% \mathrm{a}$ & $14.3 \% \mathrm{~b}$ \\
\hline Rhizopus spp. & $1.0 \% \mathrm{~b}$ & $0.4 \% \mathrm{c}$ & $0.4 \% \mathrm{c}$ & $1.5 \%$ a & - \\
\hline Penicillium spp. & - & - & - & $3.4 \%$ & $2.3 \%$ \\
\hline Curvularia spp. & - & $0.4 \%$ & $0.4 \%$ & - & - \\
\hline
\end{tabular}

statistically from each other by Tukey test at $5 \%$ probability.

In our study, there was no inhibition of infestation of Rhizoctonia solani in the treatment of cowpea seeds with Trichoderma sp. in relation to the control (Table 1). The fungus R. solani presents numerous resistance structures or sclerotia that ensures it long periods of survival (Anees et al., 2010; Nechet \& Halfeld-Vieira, 2011). In addition, a high saprophytic capacity and a wide range of host plants, cultivable or not, make this pathogen difficult to control (Nechet \& Halfeld-Vieira, 2011). In addition to not controlling infestation by $R$. solani, there was a significant increase in the percentage of infestation by Aspergillus spp. in the seeds of cowpea independently from the concentration of conidia of Trichoderma applied (Table 1).
The fungi of the genus Aspergillus, Penicillium and Rhizopus cause diseases in stored seeds, and their occurrence increases in the post-harvest period and may cause seed rot (Lazarotto et al., 2010; Siameto et al., 2010; Danelli et al., 2011 ). Fungi of the genera Trichoderma and Aspergillus may act synergistically and effectively in suppressing the growth of Fusarium oxysporum (Usha et al., 2012). Thus, it is probable that the reduction in the percentage of infestation in seeds by Fusarium spp. (Table 1) was the result of an effective interaction between isolates of Trichoderma sp. and Aspergillus spp.

Seed treatment with conidia of Trichoderma sp. did not inhibit the transmission of the fungi Fusarium spp. and Rhizoctonia solani 
from cowpea seeds to seedlings (Table 2). This result indicates that the treatment of seeds with the fungus Trichoderma sp. was inefficient in the control of these phytopathogens, allowing their occurrence in cowpea seedlings. According to Kobayasti \& Pires (2011), the pathogens carried by seeds may associate with them superficially or colonize their internal tissues, and then contaminate them. It is probable that the plant pathogens identified in cowpea seedlings were already in the inner tissues of the seeds and, after germination, infected the seedlings.

Table 2. Seed-seedling transmission and indole acetic acid (IAA) production in fungi isolated from cowpea cv. 'Vinagre' seeds inoculated with conidia of Trichoderma sp.

\begin{tabular}{ccc}
\hline Mycoflora & Transmission test* $^{*}$ & Production of IAA* $^{\text {Pat }}$ \\
\hline Positive control & Not tested & + \\
Fusarium spp. & Yes & - \\
Rhizoctonia solani & Yes & - \\
Aspergillus spp. & No & - \\
Rhizopus spp. & No & - \\
Penicillium spp. & No & - \\
Curvularia spp. & No & + \\
Trichoderma sp. & Not tested &
\end{tabular}

The fungi Aspergillus spp., Rhizopus spp., Penicillium spp. and Curvularia spp., found on the surface of cowpea seeds, were not transmitted from the seed to the seedling (Table 2). Although the fungal inoculum, in the form of mycelium or spores, is susceptible to transportation by the seed, the transmission of the pathogen depends mainly on the amount and location of the inoculum in the seed and its ability to infect the plant (Akhtar et al. 2007; Kobayasti \& Pires, 2011; Sá et al., 2011).

In our study, the fungi found by the sanity test and the isolates of Trichoderma sp. were tested as for indole acetic acid (IAA) production. Among all fungi tested, only the isolates of Trichoderma sp. produced IAA (Table 2). IAA is a plant hormone that promotes differential cell elongation and, consequently, plant growth. Trichoderma sp. isolates are efficient producers of this plant hormone (Gravel et al., 2007; Carvajal et al., 2009; Oliveira et al., 2012). According to Carvajal et al. (2009), several species of the genus Trichoderma produce both IAA and metabolites with an activity analogous to plant hormones. Once produced in excess by Trichoderma sp., the IAA plant hormone may cause a negative or inhibitory effect on germination and on seedling development (Taiz \& Zeiger, 2009).

The germination of cowpea seeds presented a positive correlation with the application of conidial concentrations of Trichoderma sp. (Figure 1A). The results indicate that Trichoderma sp. was able to stimulate the early germination of cowpea seeds. Species of Trichoderma may improve plant growth and development by producing metabolites whose activities are analogous to plant hormones (Gravel et al., 2007; Carvajal et al., 2009). In our study, the isolates of Trichoderma used were IAA producers, as shown in Table 2. IAA is considered a root initiation hormone (Brotman et al., 2010; Inácio et al., 2011).

The increase in the concentration of conidia of Trichoderma sp. stimulated more root growth (Figure 1B) and initial germination (Figure 2A) in relation to the control. Moreover, the stimulation caused by the treatment of seeds with Trichoderma sp. increased up to the concentration $4.8 \times 10^{8} \mathrm{CFU} \mathrm{g}^{-1}$ for the parameters related to germination and the length of the bean radicle (Figure 1 and 2). The application of $9.6 \times 10^{8} \mathrm{CFU} \mathrm{g}^{-1}$ conidia of Trichoderma sp. did not cause greater stimuli. It was even responsible for the decrease in the germination speed index (Figure 2B).

Although it is reported that the fungus Trichoderma sp. has several beneficial effects on plants, which include the activation of seed germination (Shoresh et al., 2010), high concentrations of this fungus imply high concentrations of auxins. Auxins and cytokinins are the main hormones related to the regulation and maintenance of cell division (Inácio et al., 2011). However, levels of auxin over the 
optimal may induce ethylene synthesis in plant tissues (Brotman et al., 2010). Ethylene is a plant hormone known to inhibit cell stretching (Taiz \& Zeiger, 2009).
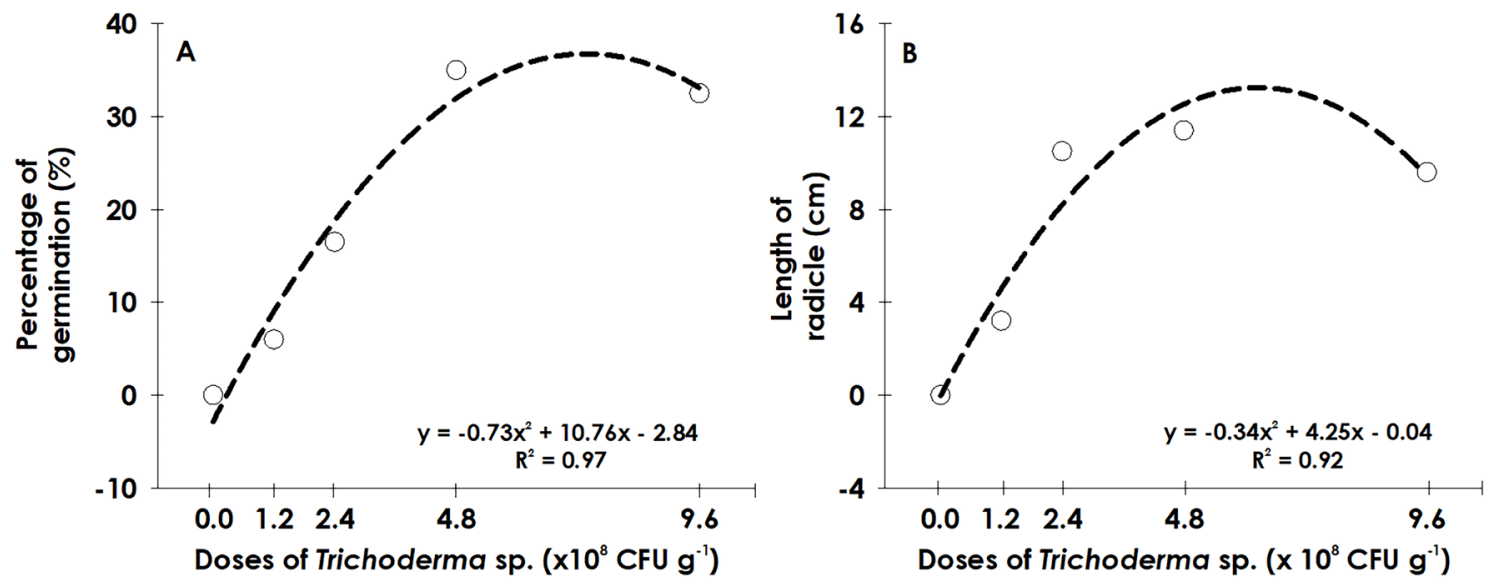

Figure 1. Percentage of germination (A) and length of radicle (B) of cowpea seeds cv. 'Vinegar' inoculated with conidia of Trichoderma sp. at the concentrations $1.2,2.4,4.8$ and $9.6 \times 10^{8} \mathrm{CFU} \mathrm{g}^{-1}$
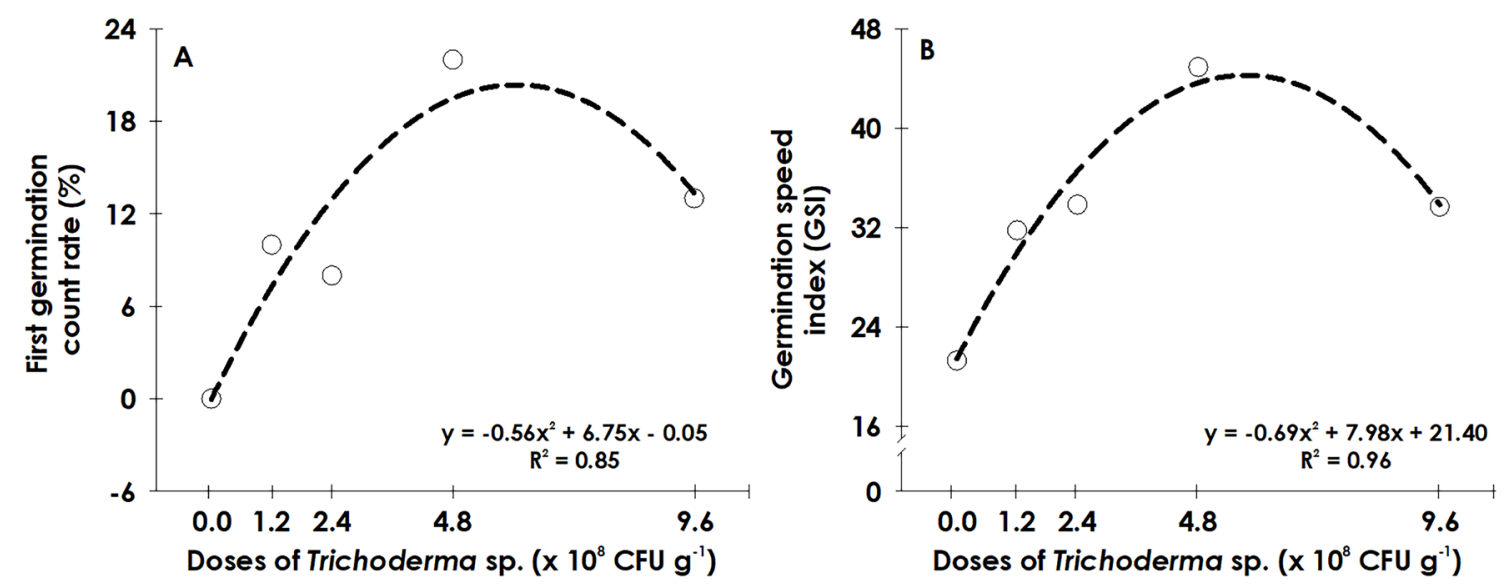

Figure 2. First germination count rate (A) and germination speed index (B) of cowpea cV. 'Vinegar' inoculated with conidia of Trichoderma sp. at the concentrations $1.2,2.4,4.8$ and $9.6 \times 10^{8} \mathrm{CFU} \mathrm{g}^{-1}$

The IAA produced by isolates of Trichoderma acts as a promoter of root growth of plant species of agricultural importance (Carvajal et al., 2009; Oliveira et al., 2012). Thus, these microorganisms may be suggested as plant growth promoters. However, it is necessary to take care with the doses applied so that there are no negative effects on plant growth, as observed with the application of $9.6 \times 10^{8} \mathrm{CFU} \mathrm{g}^{-1}$ conidia of Trichoderma sp. on the seeds evaluated. The IAA plant hormone produced by the microorganisms at low concentrations acts to stimulate growth, whereas high concentrations of this plant hormone may impair root development (Gravel et al., 2007; Inácio et al., 2011).

The treatment of seeds with antagonistic microorganisms may result in improved plant development and significant effects on germination and seedling emergence and development (Akhtar et al., 2007; Harman, 2011; Silveira et al., 2011; Oliveira et al., 2012). The fungi of the genus Trichoderma are able to act as stimulants of root growth and development, of nutrient assimilation and, consequently, of resistance to biotic stresses (Anees et al., 2010; Mastouri et al., 2010; Shoresh et al., 2010). Studies on the application of $T$. harzianum to common bean seeds did not show any symptom of toxicity or damage to seed germination. There was indeed an improvement in seed germination rates, always higher than $80 \%$, and in the percentage of normal seedlings (Carvajal et al., 2009; Mastouri et al., 2010; Carvalho et al., 2011), confirming the significant effects of the use of 
Trichoderma sp. inoculants on germination and development of cowpea seedlings.

\section{Conclusions}

The application of Trichoderma sp. was efficient in reducing the incidence of Fusarium spp., and promoted the germination and elongation of the radicle in cowpea beans.

\section{References}

Akhtar, N., Mirza, J.H., Bajwa, R., Javaid, A. 2007. Fungi associated with seeds of some economically important plants. Mycopath 5(1): 35-40.

Anees, M., Tronsmo, A., Edel-Hermann, V., Hjeljord, L., Heraud, C., Steinberg, C. 2010. Characterization of field isolates of Trichoderma antagonistic against Rhizoctonia solani. Fungal Biology 114: 691-701.

Brotman, Y., Kapuganti, J.G., Viterbo, A. 2010. Trichoderma. Current Biology 20: R390-R391.

Barbosa, T.G., Lima, L.S.L., Morais, O.M., José, A.R.S., Dourado, F.W.N., Araújo, A.G. 2011. Qualidade física e fisiológica de sementes de gramas Bermudas, Esmeralda, Japonesa e São Carlos. Revista Magistra 23(1-2): 41-44.

Carvajal, L.H., Orduz, S., Bisset, J. 2009. Growth stimulation in bean (Phaseolus vulgaris L.) by Trichoderma. Biological Control 51 (3): 409-416.

Carvalho, D.D.C., Mello, S.C.M., Lobo Júnior, M., Silva, M.C. 2011 . Controle de Fusarium oxysporum f.sp. phaseoli in vitro e em sementes, e promoção do crescimento inicial do feijoeiro comum por Trichoderma harzianum. Tropical Plant Pathology 36(1): 28-34.

Corrêa, B.O., Moura, A.B., Denardin, N.D., Soares, V.N., Schäfer, J.T., Ludwig, J. 2008. Influência da microbiolização de sementes de feijão sobre a transmissão de Colletotrichum lindemuthianum Sacc. \& Magn. Revista Brasileira de Sementes 30: 156-163.

Danelli, A.L., Fiallos, F.R.G., Tonin, R.B., Forcelini, C.A. 2011 . Qualidade sanitária e fisiológica de sementes de soja em função do tratamento químico de sementes e foliar no campo. Ciencia y Tecnología 4(2): 29-37.

Dutra, A.S., Bezerra, F.T.C., Nascimento, P.R., Lima, D.C. 2012. Produtividade e qualidade fisiológica de sementes de feijão caupi em função da adubação nitrogenada. Revista Ciência Agronômica 43(4): 816-821.

Freire Filho, F.R., Rocha, M.M., Silva, K.J.D., Ribeiro, V.Q., Nogueira, M.S.R. 2009. Feijão- caupi: melhoramento genético, resultados e perspectivas. In: Vidal Neto, F.C., Bertini, C.H.C.M., Aragão, F.A.S., Cavalcanti, J.J.V. (ed). O melhoramento genético no contexto atual. Embrapa, Fortaleza, BR. p. 25-59.

Gravel, V., Antoun, H., Tweddel, R.J. 2007. Growth stimulation and fruit yield improvement of greenhouse tomato plants by inoculation with Pseudomonas putida or Trichoderma atroviride: possible role of indole acetic acid (IAA). Soil Biology and Biochemistry 39(8): 1968-1977.

Harman, G.E. 2011. Multifunctional fungal plant symbionts: new tools to enhance plant growth and productivity. New Phytologist 189: 647-649.

Inácio, M.C., Silva, E.S., Souza, M.E., Ono, E.O., Rodrigues, J.D. 2011. Mensageiros secundários relacionados à ação dos hormônios vegetais. Revista Brasileira de Agrociência 17(4): 438-446.

Kobayasti, L., Pires, A.P. 2011. Levantamento de fungos em sementes de trigo. Pesquisa Agropecuária Tropical 41 (4): 572-578.

Kobayasti, L., Adoriam, A.I., Paiva Neto, V.B., Alves, C.Z., Zuffo, M.C.R. 2011. Incidência de fungos em sementes de pinhão-manso. Pesquisa Agropecuária Tropical 41: 385-390.

Lazarotto, M., Muniz, M.F.B., Santos, Á.F. 2010. Detecção, transmissão, patogenicidade e controle químico de fungos em sementes de paineira (Ceiba speciosa). Summa Phytopathologica 36(2): 134-139.

Machado, R.G., Sá, E.L.S., Damasceno, R.G., Hahn, L., Almeida, D., Moraes, T., Camargo, F.A.O., Reartes, D.S. 2011 . Promoção de crescimento de Lotus corniculatus L. e Avena strigosa Schreb pela inoculação conjunta de Trichoderma harzianum e rizóbio. Ciência e Natura 33(2): 111-126.

Maguire, J.D. 1962. Speed of germination-aid in selection and evaluation for seedling emergence and vigor. Crop Science 2(1): 176-177.

Mastouri, F., Björkman, T., Harman, G.E. 2010. Seed treatment with Trichoderma harzianum alleviates biotic, abiotic, and physiological stresses in germinating seeds and seedlings. Phytopathology 100(11): 1213-1221.

Nechet, K.L., Halfeld-Vieira, B.A. 2011. Efeito do inóculo, período de molhamento foliar e do estádio fenológico do feijão-caupi no desenvolvimento da mela. Tropical Plant Pathology 36: 104-109.

Oliveira, A.G., Chagas Junior, A.F., Santos, G.R., Miller, L.O., Chagas, L.F.B. 2012. Potencial de solubilização de fosfato e produção de AIA por Trichoderma spp. Revista Verde de Agroecologia e Desenvolvimento Sustentável 7(3): 149-155. 
Rey, M.S., Lima, N.B., Santos, J., Pierobom, C.R. 2009. Transmissão semente-plântula de Colletotrichum lindemuthinum em feijão (Phaseolus vulgaris). Arquivos do Instituto de Biologia 76(3): 465-470.

Rodrigues, A.A.C., Bezerra Neto, E., Coelho, R.S.B. 2006. Indução de resistência a Fusarium oxysporum f. spp. tracheiphilum em caupi: eficiência de indutores abióticos e atividade enzimática elicitada. Fitopatologia Brasileira 31: 492-499.

Sá, D.A.C., Santos, G.R., Furtado, G.Q., Erasmo, E.A.L., Nascimento, I.R. 2011. Transporte, patogenicidade e transmissibilidade de fungos associados às sementes de pinhão-manso. Revista Brasileira de Sementes 33: 663-670.

Seagro. Secretaria da Agricultura, da Pecuária e do Desenvolvimento Agrário. 2012. Feijão-caupi aumenta em $680 \%$ a área de plantio no Tocantins. http://secom.to.gov.br/noticia/27333/<Acesso em 11 Nov. 2012>.

Shoresh, M., Mastouri, F., Harman, G.E. 2010. Induced systemic resistance and plant responses to fungal biocontrol agents. Annual Review of Phytopathology 48: 21-43.

Siameto, E.N., Okoth, S., Amugune, N.O., Chege, N.C. 2010. Antagonism of Trichoderma harzianum isolates on soil borne plant pathogenic fungi from Embu District, Kenya. Journal of Yeast and Fungal Research 1: 47-54.

Silva, V.N., Guzzo, S.D., Lucon, C.M.M., Harakava, R. 2011 . Promoção de crescimento e indução de resistência à antracnose por Trichoderma spp. em pepineiro. Pesquisa Agropecuária Brasileira 46: 1609-1618.

Silveira, P.S., Vieira, E.L., Gonçalves, C.A. Barros, T.F. 2011 . Stimulate ${ }^{\circledR}$ na germinação de sementes, vigor de plântulas, crescimento inicial e produtividade de soja. Revista Magistra 23(1-2): 67-74.

Taiz, L., Zeiger, E. 2009. Fisiologia vegetal. 4. ed. Porto Alegre: Artmed, 2009.

Teixeira, H., Paula Júnior, T.J., Vieira, R.F., Silva, M.B., Ferro, C.G., Lehner, M.S. 2012. Trichoderma spp. decrease Fusarium root rot in common bean. Summa Phytopathologica 38(4): 334-336.

Usha, E., Reddy, S.A., Manuel, S.G.A., Kale, R.D. 2012. In-vitro control of Fusarium oxysporum by Aspergillus sp. and Trichoderma sp. isolated from vermicompost. Journal of Bio Innovation 1(5): 142-147.

Vinale, F., Sivasithamparam, K., Ghisalberti, E.L., Marra, R., Woo, S.L., Lorito, M. 2008. Trichodermaplant-pathogen interactions. Soil Biology and
Biochemistry 40: 1-10.

Zhang, F., Yuan, J., Yang, X., Cui, Y., Chen, L., Ran, W., Shen, Q. 2012. Putative Trichoderma harzianum mutant promotes cucumber growth by enhanced production of indole acetic acid and plant colonization. Plant Soil 18: 1-12. 